\title{
Effectiveness of domestic wastewater treatment using floating rafts a promising phyto-remedial approach: A review
}

\author{
Praveen Solanki $^{1^{*}}$, Maitreyie $\operatorname{Narayan}^{1}$ and R. K. Srivastava $^{1}$ \\ ${ }^{1}$ Department of Environmental Science, Govind Ballabh Pant University of Agriculture and Technology, Pantnagar \\ -263145 , INDIA \\ *Corresponding author E-mail: praveen.solanki746@gmail.com \\ Received: December 2, 2016; Revised received: April 18, 2017; Accepted: September 10, 2017
}

\begin{abstract}
Treatment of wastewater willeads to the problems again, if we will not use new more efficient alternative technologies/methods to avoid drawback of old technologies. Loss of water can be reduce throughapplication of easy, inexpensive and eco-friendly technologies for wastewater treatment. Using Floating rafts to purify polluted wastewater is a process/method of ecological restoration at in-situ, as well as a complicated physical (attachment of pollutants to the root surface), chemical (degradation of matels into less toxic form) and biological process (microbial processes). Its core is utilizing aquatic plants such as Canna and Water lily and root attached microbes such as bacteria, fungi and algea to absorb pollutants such as nitrogen and phosphorus, degrade organic matter and accumulates heavy metals in their biomass. Phyto-remediation of polluted wastewater using the Floating rafts technique is an Eco-friendly method of wastewater treatment, which is economically effective to construct, requires little maintenance and increase the biodiversity as different types of plants are used. Floating rafts technique has been applied to some water pollution control projects at domestic and abroad. However, there are some factors such as plants, temperature, seasons, hydraulic retention time, coverage and initial concentration of pollutants etc. influenced to the pollutants removal efficiency of Floating rafts. In the future, the development orientation has been subjected to plant and its combinations, the transformation of Floating rafts structure and the utilization of aquatic plants, and probed the technology of Floating rafts building and management, to implement the win-win of landscape benefit and ecological function.
\end{abstract}

Keywords: Attached microbial growth, Domestic wastewater, Floating rafts, Hydraulic retention time, Phyto-remediation

\section{INTRODUCTION}

Wastewater management and its treatment is very tedious process for removal of physico-chemical pollutants as well as for those techniques whichhaving lesspotentialfor removal of complex pollutants and nutrients. Hence, Floating rafts technology which is totally plants based (natural plant-based-eco-friendly) pollutants removal technique by the process called phytoremediation, maybe add into existing technologies and its application may leads to more pollutants reduction, not only because of its less installation cost, higher phytoremediation efficiency, no further production of any toxic pollutants, but also because, it can leads to further addition in ecological biodiversity as plants are used (Renand Deng, 2007). Floating rafts technique is also known as Ecological Floating Island/Artificial Floating Island, because it utilizes the technical principle of soilless culture (which is known as hydroponics) on the artificial floating platformmade up of bamboo/ PVC and plastic mess to batter supports plant growth (Ren and Deng, 2007).

Using these method for wastewater treatment, not only absorbs excess nutrients' such as $\mathrm{N}$ and $\mathrm{P}$, to reduce eutrophic level of wastewater, but also leads to further economic benefit as the plants give returns, viz. flowers, nutrients and organic matter back to the soil in the form of nutrients reach litter and so on ( $\mathrm{Hu}$ et al., 2010). In past few years, Floating rafts technology is getting mere concerned due to its higher pollutants removal rates and environmentally friendly in nature. "In the future, the development orientation will be prospected from plant and its combinations, the transformation of Floating rafts structure as well as the utilization of aquatic resources and probed the technology of Floating rafts building and management" (Faping and Xiaoyi, 2013).

Rapid growth in industrialisation and urbanisation are main causes to the more generation of municipal/ industrial wastewater, i.e., sewage, which are leads to biological and physiological degradation andserious threats to the ecosystem. Hence, it is necessary to recycle or treatment of the wastewater before it discharges into the vicinity river/environment (Mulling et al., 2014). A large number of technologies, such as sewage treatment plants (STPs), oxidation ponds or activated sludge processes, have been applied for domestic wastewater treatment but most of these practices are 
"expensive and time consuming to erect and run" (Shen et al., 2013). Therefore, it is strong need today to develop such technology which would be more efficient if pollution reduction as well as ecofriendly and sustainable in nature

In recent years, the application of Floating rafts/ Floating wetlands (with rooted and free-floating aquatic plants) and facultative ponds treating domestic/ industrial wastewater have gained considerable attention because they offer an environmentally sound approach (Chang et al., 2012; Pan et al., 2012; Avila et al., 2013; Mburuet al., 2013). The mechanisms of pollutants removal in Floating rafts/wetlands involve an "interaction between the bacterial metabolism, plant uptake and accumulation of pollutants in their biomass" (Osemet al., 2007). "The impurities are removed in facultative ponds entirely by natural processes involving both algae and bacteria" (Abdel et al., 2012). In that order, vegetation is considered as a dominant feature of Floating rafts and acts as an important biotic factor in the overall treatment process (Dhoteet al., 2009). Some of the plant's species, viz. canna, pistia and water hyacinth appears to having excellent property for pollutants removal owing to their rapid growth rate and extensive root system (Kumari and Tripathi, 2014; Olukanni and Kokumo, 2014). The plants lagoons/ponds functions as a "horizontal trickling filter", where the submerged roots provide physical support for the "bio-film bacterial to growth" (Dhoteet al., 2009). However, despite the efforts made worldwide, the construction of aquatic systems, particularly the water hyacinth treatment process, has not gained much popularity due to the requirement of a large land area and considerable capital investment (Chang et al., 2012).

Based on the oxygen transfer through the floating plants, water column can be divided into three zons, viz. aerobic, facultative and anaerobic. An excess pond depth (typically $\sim 50-100 \mathrm{~cm}$ ) reduces the oxygen transfer efficiency through the "roots and sustains high anaerobic microbial growth" (Truijenand Van, 2013; Sooknah, 2010). The oxygen concentration is likely todecrease in the direction towards bottom and it is to be high in the upper part of the lagoon/pond, approaching almost zero below a $200 \mathrm{~mm}$ depth, which can leads to rise the anaerobic zone; resulting a slower biodegradation process and cause the emission of foul odours. To overcome this drawback, a shallow pondFloating rafts system was reported and as the Floating rafts are free floating on water body by natural air circulation, hence it will add additional oxygen to the water body (Valipouret al., 2010; Valipouret al., 2015).

The shallow pond-Floating rafts is an alternative to the conventional treatment process because it has a low water depth (140-150 mm) based on the fully matured plant root submerged $(80-130 \mathrm{~mm})$ to "avoid the an- aerobic zone" (Valipouret al., 2009). Shallow pond floating raft technique ensures the optimal interactions between the wastewater effluent and microbial biomass in the phyto-remediation treatment practice. The shallow pond technique is an attempt to minimize these constraints due to the better oxygen diffusion efficiency through the roots and the accumulation of a larger aerobic bacterial population. This is a new biological-plant-basedeco-friendly technique that can be applied to the efficient and reliable elimination of pollutants at a lower hydraulic retention time (HRT) through providing of extra oxygen, as the raft are free floating in nature dute to natural air circulation (Valipouret al., 2010; Valipouret al., 2015). However, further improvements in the shallow pond practice as an effective plant-based-remediation tool for purifying municipal/industrial wastewater effluents, could be the objective for future research.

Application of phyto-remediation with attached growth -based (Plant roots and submerged plant parts provide a living surface area for development of biofilms, which contains communities of attached-growth micro -organisms responsible for a number of important treatment processes such as degradation of complex organic and inorganic molecules/pollutants in simple form) engineered procedure (using Phragmitessp.) has been reported as a new relevant technology in Floating rafts treating domestic sewage (Valipouret al., 2009; Valipouret al., 2011). The concept of operation is void of the soil strata used in the root zone systems, and in lieu a support matrix (assembled by the number of vertical and horizontal bamboo/PVC pipes) is provided to enrich the microbial population in the form of biofilm within wetland unit. This approach overcomes the limitations of choking, clogging, slow mass transfer, poor root penetration into the multilayer water column, high area requirement and capital investment owned by water bed constructed wetlands. A further study conducted by Wang and Wang, also revealed the efficiency of this method by using Thaliadealbata, Acoruscalamus, ZizanialatifoliaandIris sibiricafor river water treatment (Wang et al., 2012a; Wang et al., 2012b). Marchandet al. (2014) found effectively applied this technology for the removal of copper $(\mathrm{Cu})$ ion from synthetic $\mathrm{Cu}$-contaminated wastewaters using Phragmitesaustralis, Juncus articulates and Phalarisarundinacea. In addition, the vegetated system using Typhasp. reported to be a promising solution in domestic wastewater treatment seriously stressed with total dissolved solids (TDS) and $\mathrm{Cu}$ metal salts (Valipoueet al., 2014). The integrated anaerobic baffled reactor and phyto-remediation process with attached growth (using Phragmitessp. and Typhasp.), likewise, has been recommended as a novel approach for promoting a sustainable decentralization (Jamshidi, 2014). As a result, it is recommended by Jamshidi, 2014, that using Floating rafts systems upgraded with 
the phenomena of engineered attached growth matrix could be considered as a novel scientific advancement in domestic/industrial wastewater treatment.

Therefore, the present study aimed to enhance and examine the efficiency of the shallow pond-Floating rafts system by adding a new feature to a treatment unit. In this approach, an attempt was made to incorporate the advantages of a shallow pond and attached growth microbial techniques by introducing Floating rafts (mesh type structure), which is a support matrix to augment the indigenous microbial population. Although the performance of the water canna treatment systems has been studied elsewhere before; until now, this innovation to our knowledge has not been previously documented. This new system identified to overcome the limitations associated with the traditional methods and facultative pond technologies, and permits treatment of effluents in the most cost effective method and Eco-friendly manners. Moreover, the role of plants, microbial biofilms and evapo-transpiration in this phyto-remediation system was also important.

\section{MATERIALS AND METHODS}

The domestic/industrial wastewater or eutrophic water from River, before discharging to vicinity Rivers', can be stopped through constructing check dam in drain and can be diverted to the Floating rafts bed tank for its pollutants remediation as layout shown in Fig. 1.

The flowing volume of wastewater can be measure by $\mathrm{V}$ -Notch. The Floating rafts bed tank having size of approximate $20 \mathrm{~m}$ long, $2 \mathrm{~m}$ width and $1 \mathrm{~m}$ depth or an appropriate size shallow rectangular tank/basin with a high length to width ration will be designed and constructed with bricks and cemented concrete lining to protect any leaching towards underground. The design will take care to reduce the potential for short circuiting and to simple harvesting operations. The domestic wastewater will be directly diverted to Floating rafts bed tank at different hydraulic retention time (HRT) such as 1, 2,5,10 and 15 days for remediation of wastewater pollutants through plant roots (rhizosphere) system (Canna and Water lily). The Floating rafts will be made-up with bamboo/PVC pipe and proper netting will be done for support of plants and to form bio-film to support the maximum attached microbial population. The desired number of Floating rafts will be made with suitable size of approximate $1.4 \mathrm{~m} \times 2.1 \mathrm{~m}(2 / 3)$ in rectangular shape for the Floating rafts bed tank.

A comparative study may be carried out at different HRT for optimization of pollutants removal efficiency/ reclamation of wastewater and preparing the engineering design of large scale system for remediation/ restoration of domestic and other industrial wastewater. Biological stability of Floating rafts bed is the prime requirement for successful wastewater treatment. The plants belonging to Typha species, Reeds (Phagmites), Canna and other aquatic plants may be selected for up- take of pollutants by their roots considering existing climatic condition. Maintenance of the Floating rafts bed tank may include harvesting of plants at various interval of time and removal of detritus accumulation.

Phyto-remediation: Phyto-remediation of industrial/ domestic polluted water is generally believed to occur through one or more of the following mechanisms or processes: phyto-extraction, phyto-stabilization, phytodegradation, phyto-volatilization, rhizo-filtration and rhizo-degradation (Oh et al., 2013a; Li et al., 2009), as shown in Fig. 2 and Table 1. Phyto-remediation is applicable to a broad range of contaminants/pollutants, including heavy metals and radionuclides, as well as organic compounds like chlorinated solvents, polycyclic aromatic hydrocarbons (PAHs), pesticides/ insecticides, explosives, and surfactants (Oh et al., 2013a) (Li et al., 2009).

Phyto-remediation processes rely on the ability of plants to uptake and/or metabolize pollutants to less toxic substances (Wang et al., 2003). The uptake, accumulation and degradation of contaminants vary from plant to plant. The plants used in phyto-remediation are generally selected on the basis of their growth rate of biomass, ability to tolerate and accumulate contaminants, the depth of their root zone and their potential to transpire wastewater (Oh et al., 2013b). The plants used in phyto-remediation should not only accumulate, degrade or volatilize the contaminants, but should also grow quickly in a wild range of different conditions/ environments. As an emerging hopeful technology, phyto-remediation for using in management and remediation of contaminated water has its advantages. The most positive characteristics are that phytoremediation is a natural and in-situ remediation system driven by solar energy and green plants. It is faster than natural attenuation and can conserve the water resources. It is inexpensive, and does not induce the secondary contamination. Successful phytoremediation can reduce movement of pollutants towards groundwater and sustains the water quality. Water followed phyto-remediation are still or more suitable for its original application particularly for agricultural application, thus preventing the loss of water resources (Oh et al., 2013a; Wang et al., 2003). Because most of the energy for phyto-remediation is supplied by the Sun and phyto-remediation does not need to remove the water out of the place, the costs are very low in comparison to other physical or chemical methods of wastewater treatment.

However, as a plant-based remediation, phytoremediation has low remediation rate and generally need a longer period in comparing with other physicchemical methods. This short coming limits, its application particularly in the developed urban areas, where land is extremely expensive. The remediation rate of phyto-remediation is different with case by case, as the plant growth was influenced easily by the climate, wa- 
ter conditions and management practices. Phytoremediation has limited depth (Li et al., 2009). The use of phyto-remediation is limited by the climate, water type, geological conditions of site to be cleaned and the accessibility for agricultural equipment. Following critical consideration of these characteristics, phytoremediation can be more suitable for treatment the much larger scale contaminated water or for treatment of polluted rivers.

Research on floating rafts mechanism in polluted water restoration: Use of floating rafts for treatment of pollutedwastewater is a complicated physical, chemical and biological process. In the floating rafts technique,generally aquatic plants' developed roots are utilize to contact wastewater, forming a concentrated natural filtering layer of roots (rhizosphere), as well as absorbing, adsorption, transforming and degrading (rhizodegradation) the water pollutants. Plant's roots can also release large amount of enzyme and organic acid to enhance the decomposition and degradation of the macromolecular or toxic pollutants/substances in wastewater and improve the bioavailability of nitrogen and phosphorus to the plant roots. Plant's roots also provide microorganism with oxygen source and attachment place (root surface) and enhance their metabolism to cut down water pollutants content. Through shifting the plants out (old stem can removed) and separating them from floating platform, we will achivethe purpose of purifying water quality.

Absorption of nitrogen and phosphorus: Aquatic plants such as Canna, Water lily etc. have an enormous potential on removing of nitrogen and phosphorus elements in eutrophic water (Wang et al., 2012; Xu, 2010). Aquatic plants make the rapid accumulation of biomass (bimegnigication) come true in the way of more vegetative reproduction and removal of more pollutants from wastewater. As indispensable nutrient, elements in plants growing process, the inorganic form of $\mathrm{N}$ and $\mathrm{P}$ in water could be absorbed directly by aquatic plants through their roots' absorption (rhizoaccumulation), and then plant protein or organic component were synthesized to facilitate plant's growth and development. Therefore, plants had a strong capacity of fixing $\mathrm{N}$ and $\mathrm{P}$ as well as other nutrients/pollutants (Xuand Lu, 2011). When aquatic plants were shifted out of water of floating platform where they established, the nitrogen and phosphorus absorbed by different parts of plant such as stem, leaves and root were brought out of water too. In the research conducted on Floating rafts purification in intensive aquaculture pond, water spinach floating beds were observed highest direct absorption rates of Total Nitrogen (TN) and Total Phosphorus (TP) on the 100 days as 52.35 and $5.39 \mathrm{~kg} \mathrm{hm}^{-2} \mathrm{a}^{-1}$ respectively (Chen et al., 2010).

Canna was a very good kind of sewage treatment plant, and its highest removal rates of nitrogen and phospho- rus were 130 and $23 \mathrm{~kg} \mathrm{hm}^{-2} \mathrm{a}^{-1}$ respectively (Li et al., 2014). If the Floating rafts were made up of canna and other aquatic plants, its removal rates of $\mathrm{N}$ and $\mathrm{P}$ would be much better and the removal rates canreached 314.6 and $156 \mathrm{~kg} \mathrm{hm}^{-2} \mathrm{a}^{-1}$ respectively (Zhen et al., 2013). Cress also has observed a strong capacity of purifying eutrophic water, and its removal rates of TN and TP reached $76.86 \%$ and $90.45 \%$ at 20 days treatment period ( $\mathrm{Hu}$ et al., 2010). There was a positive correlation between Floating rafts removal rates of nitrogen and phosphorus in water and plant's growth speed, concentration of nitrogen and phosphorus in water (more the concentration of pollutants in wastewater, there was more growth of plants and removal rate of pollutants) (Jayaweera et al., 2008; Fox et al., 2008). In the research conducted by $\mathrm{Lu}$ and friends in 2000 on the water purification mechanism of aquatic plants, it is observed that plants themselves absorb $\mathrm{N}$ and $\mathrm{P}$ in water, root's microbes' activity is an important way/component of removing $\mathrm{N}$ and $\mathrm{P}$ in water, mainly because microbe's activity can accelerate the decomposition rate of $\mathrm{N}$ and $\mathrm{P}$ around roots, enhance other element's activity and improve the bioavailability of $\mathrm{N}$ and $\mathrm{P}$ to the roots ( $\mathrm{Lu}$ et al., 2000). Therefore, the exertion of Floating rafts technology's purification function not only depends on plant's absorption of $\mathrm{N}$ and $\mathrm{P}$, but a bigger factor is that, Floating rafts constructs/develop a micro ecosystem/ environment which is in favour of microbe's inhabitation so that $\mathrm{N}$ and $\mathrm{P}$ can be removed effectively in shorter of period/HRTs.

Degradation of organic matters (OMs): Floating rafts not only can remove nitrogen and phosphorus elements effectively, but it is also effective in removing organic matters (Luo et al., 2011; Bu et al., 2010). Canna and Calamus floating bed's removal rates of COD and Mn were $42.3 \%$ and $36.3 \%$ respectively in 5 days (Bu et al., 2010). However, the main ways of removing organic matters by Floating rafts were the degradation of roots secretion as well as absorption and utilization of microbes. Aquatic plants constantly secreted a great deal of macromolecular organics to the environment in the process of growth, such as enzyme, saccharide, organic acid etc. (Liu et al., 2009). Those secretions not only decomposed organic matters effectively, but it also provided root's microbes with many nutrient substances. Moreover, the oxygen produced by floating plant's photosynthesis was released to water through plant's roots (Cheng et al., 2003), then many anoxic and aerobic areas were formed around its rhizosphere to intensify both aerobic microbe's and anaerobic microbe's growth and reproduction, to promote microbe's constant absorption and utilization of organic pollutants in water and to raise its degradation efficiency of organic matters, thus achieving the propose of removing organic matters. For example, samphire's removal of humic like proteinoid, DOC and 
other organic matters were implemented by its rhizosphere's activity (Huang et al., 2013).

Enrichment of heavy metals (HMs): Aquatic plants are usually planted in Floating raft's upper layer, and many aquatic plants are capable of absorbing, metabolizing, enriching heavy metals, besides the content of heavy metals within the plants themselves was related to the outside world's pollution level, so Floating rafts was regarded as an important way of controlling heavy metals pollution in water. Hydrillavarticillata and Myriophyllumspicatum were together exposed in the different concentration such as 5, 50,100 and 1000 ppm of $\mathrm{Cu}^{2+}$ of water after two weeks (Yan et al., 2006), their absorption behaviours coincide with Langmuir model (absorption increases with increase in concentration level of pollutants) (Davis et al., 2003) and a strong enrichment capacity is manifested. Water hyacinth was a kind of plants that accumulates $\mathrm{Ni}, \mathrm{Pb}, \mathrm{Zn}$, $\mathrm{Cd}$ and $\mathrm{Cu}$ effectively, because in the wild environment water hyacinth's root's accumulations of $\mathrm{Cu}, \mathrm{Ni}$ and $\mathrm{Zn}$ are 2 to 17 times that of part above ground and their maximum bio-concentration Factor (BCF) are 1344.6, 1250.0 and 22758.6 respectively (Hammad, 2011).

The enrichments of $\mathrm{Pb}$ and $\mathrm{Cd}$ for lotus within roots of every organ were positively correlated $(+0.012$ and + 0.019 , respectively) with their concentrations (147 and $59 \mathrm{ppm}$, respectively) and an effective enrichment was demonstrated under combined stress of $\mathrm{Pb}$ and $\mathrm{Cd}$. Among all the organs, lotus leaves and swollen stems enriched the most for $\mathrm{Pb} 46$ and $53 \mathrm{ppm}$ and for $\mathrm{Cd} 19$ and $24 \mathrm{ppm}$, respectively, but the enrichment of $\mathrm{Pb}$ (Lead) and $\mathrm{Cd}$ (Cadmium) within lotus roots may cause certain toxic reactions (Xionget al., 2012). Typhalatifolia has a strong capacity of absorbing and enriching $\mathrm{Pb}, \mathrm{Zn}, \mathrm{Cd}, \mathrm{Cu}$ and they were mainly enriched at the root of plant (Yang et al., 2002). Jiang and Wang (2008) showed that after 21 days for reed to deal with $2 \mathrm{mmol} \mathrm{L}^{-1} \mathrm{Zn}^{2+}$ of sewage and after the reed is dried; its root's, stem's and leave's enrichments of $\mathrm{Zn}^{2+}$ were $14.34,0.95$ and $1.45 \mathrm{mg} \mathrm{g}^{-1}$ respectively. If canna is used to deal with copper-containing wastewater, its removal rate of $2 \mathrm{mg} \mathrm{L}^{-1}$ of coppercontaining wastewater can reach $74 \%$, and its root's, stem's and leave's maximum absorption quantities of copper are $1859.04,186.20$ and $127.53 \mathrm{mg} \mathrm{kg}^{-1}$ respectively in 10 days of experimentation (Yu et al., 2012).

Floating rafts technique application: It was 20th century, when first time use of Floating rafts technique was started and at that time it was used for bird's natural habitat and fish's spawning place for their natural restoration. In the 1980s, German scholars had decided todesign the new modern eco-friendly Floating rafts technique and used it for purify polluted water (Nakamura and Shimatani, 1997). Because of Floating rafts not only can restore polluted water (conversion to polluted wastewater into useful form), but it also pro- vides several benefits, such as less initial investments, simple operations and no production of secondary pollutants. The technique of Floating rafts for wastewater treatment was promoted and applied rapidly in Japan, Europe and America and other developed countries such as Canada, Denmark, Belgium etc. China brought Floating rafts technology in the 1990s, which is now applied to treatment of polluted urban rivers, lakes as well as reservoirs and it has a very good favourable effect on purification wastewater and development of ecological landscape. Guangzhou city used Floating rafts technique as a major natural ecological restoration measure to govern the Yufeng Chung, the south Pai Chung and Guan Chung around the Asian Games Town, as a result that water transparency was increased, water eutrophication was controlled effectively under certain level and a favourable effect of natural landscape and ecology was successfully achieved ( $\mathrm{He}$ et al., 2010; Hung et al., 2010).

The Floating raft technique had been used for several river purification projects such as the water quality improvement project of Bailian Jing River's EXPO garden section, Shanghai was one of them, a Floating rafts made up of sliver carp and bighead carp, hyriopsiscumingii and plants was constructed in section. After Nine months operation, a comprehensive water quality study was done to assess the purification efficiency of Floating raft and it was observed that the river water was transformed from Grade $\mathrm{V}$ and worse than Grade V to Grade IIandIII, respectively. It was also found that the water quality of all the floating bed sections such ascalamus, blood grass and Acorusgramineus $\mathrm{cv}$. varies gates reached the Grade of III standard, so that the river channel's water quality was improved effectively. In another water purification project of Dianshan Lake's water source, a research was conducted for one year in the water area with area of 18,000 square meters by utilizing Floating rafts technologyIt's shown that Floating rafts purified eutrophic water effectively, because DO content of pilot site at Suzhou, Jiangsu Province was increased 2.06 and 0.38 $\mathrm{mg} \mathrm{L}{ }^{-1}$ respectively as compared to that of Qiandun Riverside's inflow and that of pilot site's inflow, besides, its transparency was increased $8.1 \mathrm{~cm}$ and 7.4 $\mathrm{cm}$ respectively. The floating bed experimental project's maximum removal amount of TN, TP and COD in Qiandun Riverside's inflow was 14.9, 0.90 and 58.3 $\mathrm{g} \mathrm{m}^{-2} \mathrm{~d}^{-1}$; its maximum removal amount in floating bed site's inflow was 5.27, 0.36 and $25.13 \mathrm{~g} \mathrm{~m}^{-2} \mathrm{~d}^{-1}$ (Sun et al., 2010; Gao et al., 2011). Floating rafts technology also has an effect on controlling urban river's water quality. The research on the experiment of Xinjiao Riverside River and Huifeng River's black and smelly section showed that Floating rafts obviously removed COD by $59 \%$, TN by $86 \%$ and TP by $75 \%$; after controlling, the outflow's concentration and transparency were increased; river's biodiversity was significantly 
boosted, (as the concentration of pollutants decreases the micro and macro biota of river significantly increased); water eutrophication was obviously improved (Chen et al., 2011).

Factors of floating raft's purifying efficiency Plant: The Biological and physical properties of each plant species have vital role with regard to the removal of different types of pollutants andtheir purifying effect on water pollutants owing to different Floating rafts plant specie's different physiological properties (Mao and Zhou, 2011), therefore, selection of plant species for wastewater treatment is very important and it one of the key factors that affects water purification efficiency of floating raft technique. In the research it was observed that yellow flag floating bed's removal rates of TN and TP was 2.82 and 5.31 times higher than Canna's removal rates, besides it, yellow flag was proposed as the major plants of urban water Floating rafts because of its freeze resistant capacity was much stronger than other plants such as Canna (Wu et al., 2010). There was an obvious discrepancy among canna's, thaliadealbata's and willow herb's removal rates of TN $(79,84$ and $68 \%$, respectively) and TP $(85$, 78 and $74 \%$, respectively) and both canna's and dealbata's removal rates of $\mathrm{TN}$ and $\mathrm{TP}$ were higher than that of willow herb (Jiang et al., 2011).

Research on applying four plant floating bed species such as canna, cyperusaltrnlifolius, pontederiacordata and calamus to improve the eutrophic water in tribu- tary area of The Three Gorges Reservoir showed that canna's maximum removal rate of TP $(87 \%)$ was higher than that of cyperusaltrnlifolius (76\%), pontederiacordata $(73 \%)$ and calamus (67\%) (Mishra et al., 2008). It was usually observed that the purifying effect of the floating bed plants with developed roots was better than that of the floating bed plants with undeveloped roots, because the developed root system have larger rhizospher zone and also have longer root hair to absorb more and more pollutants; the purifying effect of the floating bed plants with high growth rate was better as they absorb quickly and more nutrients/ pollutants and organic matter from wastewater (Ge et al., 2000). That's mainly because plants with developed roots and with high growth rate could obtain more component/pollutants, thus plant's purifying effect of water pollutants/contaminants was more facilitated.

Temperature: Among, factors affecting the efficiency of floating raft treatment, temperature aremost important which play a vital role in plant's growth and reproduction. Temperature is positively correlated with plant's purifying capacity, when the temperature is high, floating bed plant's growth and their metabolism is vigorous and plant's purifying effect of water pollutants is obviously improved and as the plant become more healthy, they accumulates more pollutants in their tissues. It was observed that, when the water temperature was increased from $2^{\circ} \mathrm{C}$ to $29^{\circ} \mathrm{C}$, canna's re-

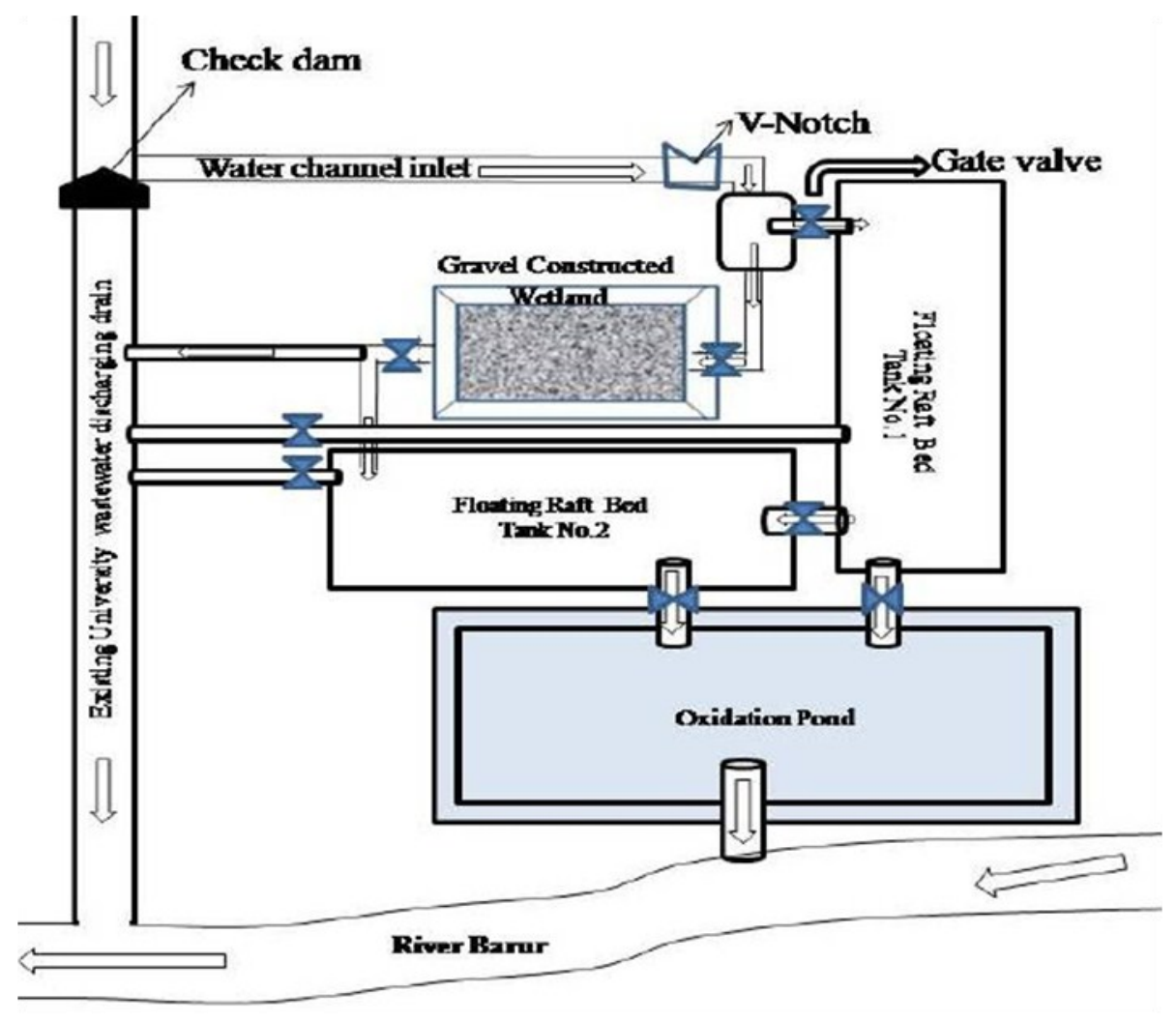

Fig. 1. Proposed layout of Floating rafts tank (proposed for future research). 


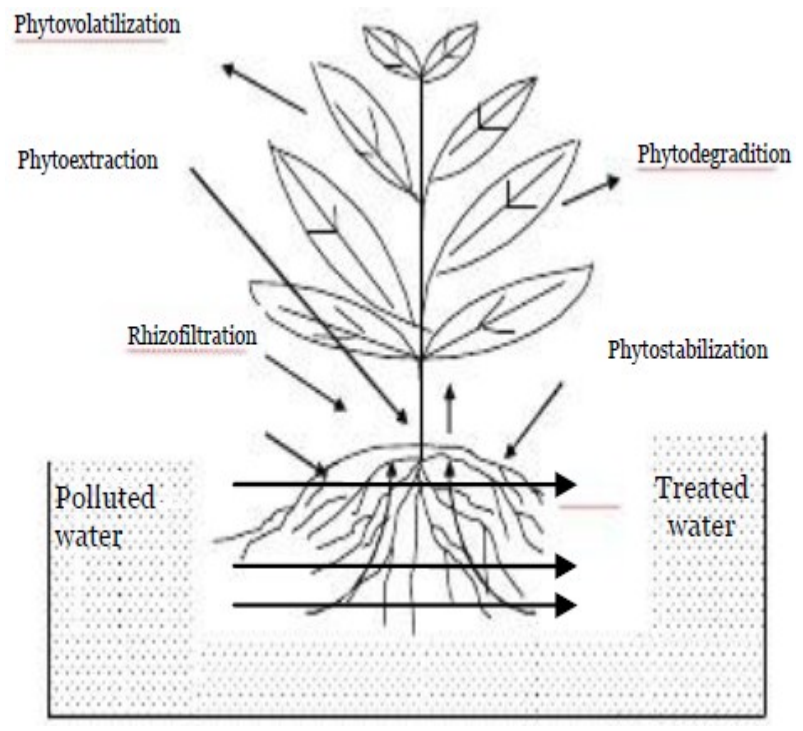

Fig. 2. Phyto-remediation of industrial/domesticpolluted water(Ferreiroet al., 2014).

moval rates of TN (Total Nitrogen) and TP (Total Phosphorus) were distinctly increased by $57 \%$ and $63 \%$, respectively as compare to at $2^{\circ} \mathrm{C}$. When the temperature was raised beyond $10^{\circ} \mathrm{C}$, canna removal rate of TP and $\mathrm{TN}$ inform wastewater obviously increases; and when the temperature was lower than $10^{\circ}$ C, canna's growth rate was at a standstill (Zhen et al., 2008; Luo et al., 2010). In another researchit was observed that cress floating bed's and water cress floating bed's removal rates of TN and TP from eutrophic water at $22^{\circ} \mathrm{C}$ were clearly higher than that of at $10^{\circ} \mathrm{C}$ and $35^{\circ} \mathrm{C}$ (Hu et al., 2010); Eichhorniacrassipes floating bed's removal rates of TN and TP from eutrophic water at $25^{\circ} \mathrm{C}$ washigher than that of $15^{\circ} \mathrm{C}$ and $35^{\circ} \mathrm{C}$ temperature.

It was also observed that, plant's removal rates of TN and TP were not proportional to the temperature, but the temperature wasvery important factor that affect to the floating bed plant's biomass and more the plant biomass, more will be accumulation of pollutants (Liu et al., 2013). As discussed in above paragraph, plant's growth rate was different at different temperaturesand the growth of plants were very good at the optimum temperature condition and its purifying effect for polluted water was obvious mare as compare to very high or low temperature conditions where plant's growth was restrained, thereby,plant's purifying effect of polluted wastewater was influenced greatly by temperature.

Seasonal variation also well affects the plant's purifying effect. Floating raft's removal rates of TN and TP in summer (78 and $65 \%$, respectively) and autumn (82 and $74 \%$, respectively) were significantly higher than in winter (62 and 58\%, respectively) and spring (75 and $63 \%$ respectively), and the reason behind the performance was that, floating bed plant's pollutants re-
Table 1. Phyto-remediation processes for restoration of contaminated water (Ferreiroet al., 2014).

\begin{tabular}{|c|c|}
\hline $\begin{array}{l}\text { Phyto- } \\
\text { remediation } \\
\text { Processes }\end{array}$ & Description \\
\hline $\begin{array}{l}\text { Phyto- } \\
\text { extraction }\end{array}$ & $\begin{array}{l}\text { Plants absorb contaminants and store in } \\
\text { above-ground shoots and the harvestable } \\
\text { parts of roots. }\end{array}$ \\
\hline $\begin{array}{l}\text { Phyto- } \\
\text { stabilization }\end{array}$ & $\begin{array}{l}\text { Roots and their exudates immobilize } \\
\text { contaminants through adsorption, accu- } \\
\text { mulation, precipitation within the root } \\
\text { zone, and thus prevent the spreading of } \\
\text { contaminants. }\end{array}$ \\
\hline $\begin{array}{l}\text { Phyto- } \\
\text { degradation }\end{array}$ & $\begin{array}{l}\text { Plant enzymatic breakdown of organic } \\
\text { contaminants, both internally and } \\
\text { through secreted enzymes. }\end{array}$ \\
\hline $\begin{array}{l}\text { Rhizo- } \\
\text { degradation } \\
\text { (phyto- } \\
\text { stimulation) }\end{array}$ & $\begin{array}{l}\text { Plant roots stimulate water microbial } \\
\text { communities in plant root zones to break } \\
\text { down contaminants. }\end{array}$ \\
\hline $\begin{array}{l}\text { Phyto- } \\
\text { volatilization }\end{array}$ & $\begin{array}{l}\text { Contaminants taken up by the roots } \\
\text { through the plants to the leaves and are } \\
\text { volatized through stomata where gas } \\
\text { exchange occurs. }\end{array}$ \\
\hline
\end{tabular}

moval efficiency was proportional their own growth condition and metabolism which wasobviously higher in summer and autumn seasons (Zhang et al., 2010). Summer and autumn seasons are temperature bias floating bed plant's vigorous periods of growth, hence, the plants performed a high purifying rate as compare to winter and spring (Sun et al., 2008). However, there're research which was conducted at Department of Biology, Sinop Art and Science Faculty Sinop University SinopTurkeyindicating that canna floating bed's removal effect of nitrogen in spring was better than in autumn (Sivaciet al., 2008), because spring and summer were canna's growth periods, and it primarily stops growing and began to fall off after the $15^{\text {th }}$ of July (Ge et al., 2000).

Processing time/hydraulic retention time (HRT): Floating rafts plant's pollutants removal efficiency are proportionally related to processing time or hydraulic retention time such as more the pollution level of wastewater, more processing time will required. For example, yellow flag, canna and siberian iris floating bed's purifying capacity for nitrogen and phosphorus in polluted water increased with the growth of time of plants (Chen et al., 2011). Lycopus, wood betony, rumex japonicas and garden sorrel floating bed's purifying effects of $\mathrm{N}$ and $\mathrm{P}$ in sewage increased with the growth of time, moreover, in the initial 30 days plant's removal efficiency were obvious, while after 30 days plants removal rates of contaminants ware declined $(\mathrm{Xu}, 2010)$. With the growth in the processing time (such as 24, 48, 72 and 96 hours), watermifoil'sand water caltrop's enrichments of $\mathrm{Cd}^{2+}$ increased proportionally. (Zhen et al., 2008). Study conducted by Luo and friends have found that with the growth of pro- 
cessingtime, the removal rate of water pollutants had the tendency to firstly increase and then decrease (Luo et al., 2010). Ajayi and Ogunbayo used water hyacinth in 2012 to purify sewage and found that the content of $\mathrm{BOD}, \mathrm{Fe}$ and $\mathrm{Cu}$ in water firstly increases and two weeks later gradually decreases.

Coverage: Pollutants purifying efficiency of plant's used in the Floating rafts technique is proportionally directly related to floating bed's/coverage area by plants: such as the coverage increases, the purifying efficiency of plant's will be improved simultaneously. For example, as compared to $10 \%$ coverage and $15 \%$ coverage area with water spinach floating beds, there was more removal of nitrogen and phosphorus with $20 \%$ coverage of spinach floating bed and its economic value was higher (Xu, 2010; Hu et al., 2010). Floating bed planted with Cyperusalternifolius observed the removal rates of $\mathrm{N}$ and $\mathrm{P}$ from eutrophic water also had the tendency to increase with the increasing growth of coverage area $(39 \%>26 \%>13 \%)$ (Liu, 2013). Among different coverage area (50, 60, 70 and $80 \%$ ) of water hyacinth's it was observed that, purifying effects of plant's for TN (total nitrogen) and TP (total phosphorus) in water raised with the increase of water hyacinth's coverage area, in addition, when plant's coverage area was more than $80 \%$ in flowing water, the removal rates of pollutants were higher; while when its coverage area was $<50 \%$, the purifying effects were better (Wang et al., 2012).

Initial concentration of wastewater: Initial pollution level of wastewater pollutants/contaminants is one of the most important factors that affect the Floating rafts purifying efficiency. Sometime within the threshold limits of pollutant also may leads death to the plants; it was also observed that, greater water pollutant's concentration in wastewater, there was stronger absorbing ability of plants for pollutants (Zhang et al., 2010). In the another research it was also found that, with increases the concentration of nitrogen in wastewater from 0 to $200 \mathrm{mg} \mathrm{L}^{-1}(0,40,80,100,150$ and $200 \mathrm{mg}$ $\mathrm{L}^{-1} \mathrm{~N}$ ), the removal rates of nitrogen by water hyacinth was also increased correspondingby the amounts of $0.47,5.69,9.31,11.86,16.97,22.13 \mathrm{mg} \mathrm{L}^{-1}$ (Zhang et al., 2010). The research on water hyacinth's also found that, the enrichments of 0 to $4 \mathrm{mg} \mathrm{L}^{-1}$ of $\mathrm{Cd}$ and $\mathrm{Zn}$ in wastewater showed the increment of absorbed concentration of $\mathrm{Cd}$ and $\mathrm{Zn}$ in plant parts such as roots and buds (Sivaci et al., 2008).

\section{Prospects}

Plants selection: The selection of plant species for Floating rafts is one of the most important aspects of Floating rafts research. Selection of plant should be according to climatic condition of that particular area where this technique is to be installed. When plant are selected for polluted wastewater restoration, usually one should prefer aquatic plants with the more biomass production, more pollutants strong capacity, well stain resistance and high removal rate of pollutants/ contaminants as floating bed plants, and some other factors also should be concedersuch as regional weather characters, freeze resistance capacity and seasons. It was commonly observed that, most aquatic plants have a low freeze resistance capacity and are more vulnerable to the chilling injury; hence the plant's ability of removing pollutants obviously decreases in lowtemperature in season of winter. In the future, the research on selection of aquatic plants those are more capable to successfully grow in low-temperature or freezing environmental condition and have a strong capacity of absorbing multiple pollutants from the wastewater should be strengthened. There are number of technique such as using plant tissue culture, to select plants not only cut down the cost of installation and it was not limited by seasons condition, but it also enhanced plant's restoration capacity, so it would be a research hotspot in the upcoming future (Ajayi and Ogunbayo, 2012).

Application of the Floating rafts along with combination of different plants species to restoration of polluted waste water in the aquatic environment is leads to a research direction for the future generation. At present it was observed that, most research have been focused on the single plant's purifying capacity for polluted water, but it was also observed that it is difficult for a single plant to overcome all the factors that affect purifying effect of that particular plant, hence plant's ability to purifying is limited up to some level. However, use of complex form of Floating rafts which are prepared by multiple phytoremedial plant scan overcome the various disadvantage of a single plant such as unstable purifying effect in different seasonal variations. (Xu and Lu, 2011; Chao et al., 2011), combination of different plants together can also enhanced the advantage of various aquatic plant's characteristics such as growth difference in time and space and achieve Floating rafts continuous and stable operation through optimal configuration. Nevertheless, the best combination of phytoremedial aquatic plant for maximum removal of pollutant, are still requires strengthened research in the field level experiments.

Improvement of floating rafts: Traditional Floating platform in the technique of Floating rafts is mainly made using floating bed body such as bamboo, floating bed matrix such as plastic mat and floating bed aquatic plants, which are capable to cuts down nutrients viz., nitrogen, phosphorus, heavy metals, organic load (BOD, COD, TOC), but effect of this technique for wastewater restoration is undesirable and hence it is necessary to modify this technique for more pollutants removal capacity. Structural modification of floating raft along with hyper accumulator plant species could be one of the ways for future research to enhance floating bed's pollutants removal strength (Liu et al., 2011). 
Now a days this technique is combination of floating bed system, contact oxidation system, aerating system, aquatic phytoremedialplants, microbes, paddings and biological/natural oxidation purification tanks, which all together leads to full advantage of floating bed's cubical space, lengthens food chains in floating bed system and strengthens floating bed's enrichment specialty of microbes, immobilised enzymes, thus enhancing purifying effect (Wang and Cheng, 2010).

In some researchit was shown that a new frame-type floating bed which was made up of aquatic plants, paddings and microbes also by using the principle of biological symbiosis mechanism, and its purification strength was obviously better as compared to traditional floating bed method (Fox et al., 2008). Li had alsodevelopeda combined cubical floating bed ecological system and its main body was made up of aquatic plants, aquatic animals and microbes and this combination was proved better removal rate of contaminants/ pollutants(Zhao et al., 2011). Development of complex form of Floating rafts structure makes plants, paddings and microbes function together as the primary objective in pollutants removal strength instead of only plants, but how each components are organised together and can leads to improve purifying capacity more effectively and this can be again remains as to be further studied of interest upcoming in the future ( $\mathrm{Lu}$ et al., 2004).

Resource utilization of aquatic plants: Aquatic plants are supposed to be growing rapidly and they also have capacity to gain large biomass in less time. Nutrients such as Nitrogenand Phosphorus etc.which wereabsorbed by plants can be transformed into proteins, amino acids and other nutrient materials and have certain economic value also (Zhou et al., 2006). As the aquatic plants have certain age limit and hence they require pruning on time otherwise plants will decay in wastewater, and as a result of that, this not only leads to production of secondary pollution but also leads to wastes of valuable resources (Chen et al., 2010). At present, aquatic plants are used in the form of phyto-extraction, exploitation for medical purpose, forage production for animals (Fan et al., 2011) and edible vegetables for human being etc., ( $\mathrm{Li}$ et al., 2008). However, the performance of aquatic plant for excess removal of pollutants from wastewater is yet one of the important limiting factors of their ecological restoration in the aquatic environment/condition, and new methods and modification in this technique according to level of pollutants to enhance the performance of floating raft will be a future research direction.

Engineering application: Since long ago, Floating rafts technique is used as an aquatic plants based treatment method for wastewater and eutrophic water. There are many engineering techniques at bothdomestic and international level having gotten good purifying effect, but they also simultaneously having many problems also such as high installation cost, production of secondary pollutants, management of generated sewage sludge etc. However, Floating raft is plant based method of purification, its purifying capacity also depends upon certain climatic factors such as humidity, temperature, wind velocity, mean sea level etc.Nevertheless, once the growth of plant reached to the saturation stage, removal of these plants again will be time consuming and require labour cost (Guoand Zhang, 2010)

Plants used in the Floating rafts require daily care as they are vulnerable to the certain pest and disease with reference to the environmental condition and if the management of plants fail to form systematic specification; Floating rafts working life become short, usually $<6$ years (Guoand Zhang, 2010); still there are no technology and management standards to reference in engineering application of floating raft technique. However, Floating rafts technique has excellent merits and above problems/demerits are hindering Floating rafts technology's application and promotion. Therefore, the use of Floating raft technique in combination with technology at broad and field level needs further systematically research.

\section{Conclusion}

It has been observed that phyto-remediation of wastewater using the Floating rafts technique is a predominant method which is cost effective to construct as compare to other traditional methods, requires little ornegligible maintenance and increase the biodiversity as the aquatic plants are used. However, different plant species such as Canna, Water lily, Pistia etc, having different pollutants (like TSS, TDS, BOD, COD, EC, hardness, heavy metals, nitrogen phosphorus, etc) removal rate under different conditions. Removal of pollutants also depends upon plant growth stage and hydraulic retention time and initial concentration of pollutants. Many researchers had been concluded; the combination of different plant species had more pollutants removal rates as compare to using single plant species.

\section{ACKNOWLEDGEMENTS}

This review study was supported by Indian Institute of Technology (IIT), New Delhi (India) under project entitled "Integrated Technology System for Phytoremediation of Domestic Wastewater with Floating Rafts (Floating Wetland): R\&D and Pilot Testing”. The authors are very grateful to the researchers for their results have been used in this review.

\section{REFERENCES}

Abdel, R.N., Al-Homaidan, A.A. and Ibraheem, I.B.M. (2012).Microalgae and wastewater treatment. Saudi J. Biol. Sci. 19: 257-275. 
Ajayi, T.O. and Ogunbayo, A.O. (2012).Achieving Environmental Sustainability in Wastewater Treatment by Phyto-remediation with Water Hyacinth (Eichhorniacrassipes).Journal of Sustainable Development. 5(7) : 80-90.

Avila, C., Salas, J.J., Martín, I., Aragón, C. and García, J. (2013). Integrated treatment of combined sewer wastewater and stormwater in a hybrid constructed wetland system in southern Spain and its further reuse. Ecol. Eng. 50 : 13-20.

Bu, F.P., Luo, G.Y., X.Y. and Xu.(2010).Canna indica and AcorusCalamus Ecological Floating Beds for Purification of Micro-Polluted Source Water.China Water \& Wastewater. 26(3) : 14-17.

Chang, J.J., Wu, S.Q., Dai, Y.R., Liang, W. and Wu, Z.B. (2012). Treatment performance of integrated verticalflow constructed wetland plots for domestic wastewater. Ecol. Eng. 44 : 152-159.

Chao, S., Chen, J.Z. and Ge, X. P..(2011). The Control of Nitrogen and Phosphorus to Tilapia Fish Pond by Floating- Bed-Grown Water Spinach (Ipomoea aquatica).Chinese Agricultural Science Bulletin. 27(23) : 7075.

Chen, J.Z., Meng, S.L. and Hu, H.D..(2010). Effect of Ipomoea Aquatic Cultivation on Artificial Floating Rafts on Water Quality of Intensive Aquaculture Ponds.Ecology and Environment in the Countryside., 26 (2) : 155-159.

Chen, X.H., Sun, C.J., Cao, Y. and Gao, Y.J. (2010). Research on Effects and Factors of Applying Ecological Floating Bed Technology to Governing Eutrophic Shallow Lakes.Proceedings of the 2010 Academic Annual Meeting of Chinese Society for Environmental Sciences. $3: 2595-2600$

Chen, Y.H., Zhang, Y. and Huang, M.S..(2011). Demonstration Work on Purification of Urban Polluted Rivers by Staged Floating Treatment Wetlands. Journal of East China Normal University (Natural Science Edition).1 : 111-118.

Cheng, X.P., Wu, Z.B. and Xia, Y.Z. (2003). Review on Gas Exchange and Transportation in Macrophytes. ActaHydrobiologicalSinica. 27(4) : 413-417.

Davis, T.A., Volesky, B. and Mucci, A. (2003).A Review of the Biochemistry of Heavy Metal Biosorption by Brown Algae.Water Research.37 : 4311-4330.

Dhote, S. and Dixit, S. (2009). Water quality improvement through macrophytes-A review.Environ. Monit.Assess. 152: 149-153.

Fan, J.Q., Zou, G.Y. and Song, X.F. (2011).Effects of FCEFB and TFB on the Nitrogen Removal and Nitrogen Cycling Microbial Community in a Eutrophic River.Research of Environmental Science. 24(8) : 850-856.

Faping, B. and Xiaoyi, X. (2013). Planted floating bed performance in treatment of eutrophic river water. Envi Moni Asses. 185: 9651-9662.

Ferreiro, P.J., Lu, H., Fu, S., Mendez, A. and Gasco, G. (2014). Use of phytoremediation and biochar to remediate heavy metalpolluted soils: a review. Solid Earth.5 : 65-75.

Fox, L.J., Struik, P.C. and Appleton, B.L. (2008). Nitrogen Phyto-remediation by Water Hyacinth (Eichhorniacrassipes(Mart.) Solms).Water Air Soil Pollut. 194 : 199-207.
Gao, Y.J., Ruan, R.L. and Sun, C.J. (2011). Research on Purification Effect of Ecological Floating Bed Experimental Project in Qiandunpu Estuary Region in Dianshan Lake.Water Resources Protection. 27(6) : 28-31.

Ge, Y., Chang, J. and Wang, X.Y. (2000).Relationship between the Physiological Characters and Purification Ability of Different Plants in Waters with Two Trophic Levels.Acta Ecological Sinica. 20(6) : 1050-1055.

Guo, B. and Zhang, W. (2010).Application of Ecological Floating Bed in Dianshan Lake's Eutrophic Water Restoration.China Science and Technology Information.23 : 343-352.

Hammad, D.M. (2011).Cu, Ni and Zn Phyto-remediation and Translocation by Water Hyacinth Plant at Different Aquatic Environments.Australian Journal of Basic and Applied Sciences. 5(11) : 11-22.

He, M.M., Zhu, C. and He, Z.J. (2010).Application and Landscape Effects of Eco-Floating Bed in the Guangzhou Asian Games City's River.Guangzhou Garden.6 : 10-13.

Hu, M.H., Yuan,J.and Yang, X.E. (2010).Eutrophication Purification and Resource Utilization by Aquatic Vegetables.Journal of Lake Sciences. 22(3) : 416-420.

Hu, M.H., Yuan, J.H. and Yang, X.E. (2010). Effects of Temperature on Purification of Eutrophic Water by Floating Eco-Island System.ActaEcological Sinica.30 : 310-318.

Huang, L.F., ZhuoJianfu, J.F.nad Guo, W.D. (2013). Tracing Organic Matter Removal in Polluted Coastal Waters via FloatingbedPhyto-remediation.Marine Pollution Bulletin. $71: 74-82$.

Huang, Y.Y., Jiang, M. and Zhang, Y.J. (2010).Building Artificial Floating-Island for Treating Bailianjing River in Shanghai.Environmental Science and Technology. 33 (8) : 108-133.

Jamshidi, S., Akbarzadeh, A., Woo, K.S. and Valipour, A. (2014). Wastewater treatment using integrated anaerobic baffled reactor and Bio-rack wetland planted with Phragmitessp. and Typhasp. Environ. Health Sci. Eng. 12 : 131-143.

Jayaweera, M.W., Kasturiarachchi, J.C. andKularatnea, R.K.A. (2008). Contribution of Water Hyacinth (Eichhorniacrassipes (Mart.) Solms) Grown under Different Nutrient Conditions to Fe-removal Mechanisms in Constructed Wetlands.Journal of Environmental Management. 87(3) : 450-460.

Jiang, X. and Wang, C. (2008). Zinc Distribution and ZincBinding Forms in PhragmitesAustralis under Zinc Pollution. Journal of Plant Physiology. $165:$ 697-704.

Jiang, Y., Tong, Y. and You, W.H. (2011). Research on Comparison of the Growth Characteristics and the Optimize Configuration Modes of the Nitrogen and Phosphorus Uptake Capacity of Three Kinds of Plant Cultivated on the Floating-Bed. China Environmental Science. 31(5) : 774-780.

Kumari, M. and Tripathi, B.D. (2014).Effect of aeration and mixed culture of Eichhorniacrassipesand Salvinianatanson removal of wastewater pollutants.Ecol. Eng.62: 48-53.

Li, F., Fan, Z., Xiao, K., Oh, X., Ma. and Hou, W. (2009). Contamination, chemical speciation and vertical distribution of heavy metals in soils of an old and large industrial zone in Northeast China.Environ. Geol. 57 : 1815-1823. 
Li, L., Yang, Y. and Yang, F.J. (2011). Growth Characteristic Features and Behaviors of Aquatic Plants in the Polluted Water.Journal of Safety and Environment. 11(3) : 14-19.

Li, W., Li, X.N. and Cao, D.W. (2008).Effect of Combined Ecological Floating Bed Technology on Improvement of Eutrophic Source Water Quality.China Water \& Wastewater. 24(3) : 34-38.

Liu, F.M. (2013). Effect of Temperature on EichhorniaCrassipes Floating Island Purification.Environmental Protection Science. 39(3) : 9-11.

Liu, W., Qiu, J.R. and Wei, Z.B. (2009).Effects of Different Plants and Plant Root Exudates on Wastewater Purification.Journal of Environmental Engineering. 3(6) : 971976.

Liu, Y.Q., Zou, G.Y. and Song, X.F. (2011). Response of Phytoplankton Community to a New Ecological Floating Bed System (EFBS) in Enclosures with Eutrophicated Water.Research of Environmental Science. 24 (11) :1233-1239.

Lu, K.H., Hu, R.Y. and Liang, J.J. (2000). Characteristics of Rhizosphere Microbial Community Structure of Two Aquatic Plants in Eutrophic Waters.China Environmental Sci. Technol. 6: 49-57.

Lu, X.M., Maleeya, P. and Prayad(2004).Removal of Cadmium and Zinc by Water Hyacinth, Eichhorniacrassipes.Science Asia. 30 : 93-103.

Luo, G.Y., Bu, F.P. and Xu, X.Y. (2010). Effect of Temperature on the Ecological Floating bed System. China Environmental Science. 30(4) : 499-503.

Luo, S.T., Zhang, Y.J. and Li, J.Y. (2011). Effect of Combination of Submerged MacrophyteWith Ecological Floating Bed on Aquacultural Pollution Controlling. Journal of Ecology and Rural Environment. 27(2) : 8794.

Mao, X.R. and Zhou, J.B. (2011).Research on Water Quality Purification Capacity of Several Species of Aquatic Plants Commonly Used by Ecological Floating Bed.Journal of Zhejiang Agricultural Sciences.1 : 157159.

Marchand, L., Nsanganwimana, F., Oustriere, N., Grebenshchykova, Z., Lizama-Allende, K. and Mench, M. (2014). Copper removal from water using a bio-rack system either unplanted or planted with Phragmitesaustralis, Juncus articulates and Phalarisarundinacea. Ecol. Eng. 64 : 291-300.

Mburu, N., Tebitendwa, S.M., van Bruggen, J.J.A., Rousseau, D.P.L. and Lens, P.N.L. (2013). Performance comparison and economics analysis of waste stabilization ponds and horizontal subsurface flow constructed wetlands treating domestic wastewater: A case study of the Juja sewage treatment works. Environ. Manag. 128 : 220-225.

Mishra, V.K., Upadhyay, A.R., Pandey, S.K. and Tripathi, B.D. (2008). Concentrations of Heavy Metals and Aquatic Macrophytes of GovindBallabh Pant Sagar an Anthropogenic Lake Affected by Coal Mining Effluent. Environmental Monitoring and Assessment. 141 : 49-58.

Mulling, B.T.M., Soeter, A.M., Van Der Geest, H.G. and Admiraal, W. (2014). Changes in the planktonic microbial community during residence in a surface flow constructed wetland used for tertiary wastewater treatment. Sci. Total Environ. 881-887.

Nakamura, K. and Shimatani, Y. (1997).Water Purification and Environmental Enhancement by the Floating Wetland.Proceeding of 6th IAWQ Asia-Pacific Regional Conference in Korea.

Oh, K., Li, T., Cheng, H., Hu, X., Lin, Q. and Xie, Y. (2013). A Primary Study on Assessment of Phyto-remediation Potential of Biofuel Crops in Heavy Metal Contaminated soil. Applied Mechanics and Materials. 1135-1138.

Oh, K., Li, Y., Cheng, Y., Xie, and Yonemochi. S. (2013).Development of Profitable Phyto-remediation of Contaminated Soils with Biofuel Crops.Journal of Environmental Protection. 4 : 58-64.

Olukanni, D.O. and Kokumo, K.O. (2014).Efficiency assessment of a constructed wetland using Eichhorniacrassipesfor wastewater treatment.Am. J. Eng. Res. 2 : 450454.

Osem, Y., Chen, Y., Levinson, D. and Hadar, Y. (2007). The effects of plant roots on microbial communitystructure in aerated wastewater-treatment reactors. Ecol. Eng.,29: 133-142.

Pan, J., Zhang, H., Li, W. and Ke, F. (2012). Full-scale experiment on domestic wastewater treatment by combining artificial aeration vertical- and horizontal-flow constructed wetlands system. Water Air Soil Pollut.223 : 5673-5683.

Ren, Z.Y. and Deng, C.G. (2007).Application of Ecological Floating Bed Technology.Journal of Agro-Environment Science. $26: 261-263$.

Shen, D.S., Huang, B.C., Feng, H.J., Zhao, B., Zhao, J.M., Zhang, H.Y. and Liu, P.Q. (2013). Performance of a novel decentralised sewage treatment reactor. J. Chem. $1-6$.

Sivaci, A., Elmas, E. andGumus, F.(2008). Removal of Cadmium by MyriophyllumHeterophyllumMichx and Potamogetoncrispus L. and Its Effect on Pigments and Total Phenolic Compounds.Archives of Environmental Contaminationand Toxicology.54 : 612-618.

Sooknah, R.A. (2010). Review of the mechanisms of pollutant removal in water hyacinth systems. Science. 30 (11) : 1508-1515.

Sun, C.J., Gao, Y.J. and Cao, Y. (2010). Study on Design and Effect of Estuary Ecological Floating Bed Pilot Project at Dianshan Lake. China Water \& Wastewater. 26(18) : 64-68.

Sun, L.P., Liu, Y. and Feng, C. (2008).Removal of Nitrogen from Water Bodies by Canna Floating Bed in Different Seasons.Journal of Sun Yat-sen University (Natural Science Edition). 47(2) : 127-130.

Truijen, G. and Van, P.G.M. (2013).Constructed Wetland and Aquatic Treatment Systems for Fish Farms in Egypt: Desk Study Report; Centre for Development Innovation, Wageningen UR: Wageningen, Netherlands.2013.

Valipour, A., Hamnabard, N., Woo, K.S. and Ahn, Y.H. (2014). Performance of high-rate constructed Phytoremediation process with attached growth for domestic wastewater treatment: Effect of high TDS and $\mathrm{Cu} . J$. Environ. Manage.145 : 1-8.

Valipour, A., Raman, V.K. andGhole, V.S. (2009).A new approach in wetland systems for domestic wastewater treatment using Phragmitessp. Ecol. Eng. 35 : $1797-$ 1803

Valipour, A., Raman, V.K. and Ghole, V.S. (2011). Application of patent bio-rack wetland system using phragmitessp. for domestic wastewater treatment in the pres- 
ence of high total dissolved solids (TDS) and heavy metal salts. Environ. Sci. Eng.53 : 281-288.

Valipour, A., Raman, V.K. and Ghole, V.S. (2015).Phytoremidation of domestic wastewater using Eichhorniacrassipes.Environ. Sci. Eng. 53 : 183-190.

Valipour, A., Raman, V.K. and Motallebi, P. (2010). Application of shallow pond water hyacinth system for domestic wastewater treatment in the presence of high total dissolved solids (TDS) and heavy metal salts. Environ. Eng. Manag. 9 : 853-860.

Wang, J.Q., Zhi, Y.F. and Song.(2012). Purification Effect of Water Hyacinth (Eichhorniacrassipes) Coverage on the Different Flow Properties Water Bodies.Ecology and Environmental Sciences. 21(1) : 124-129.

Wang, J., Zhang, L., Lu, S., Gan, S. andJin, X.C. (2012b). Removal of $\mathrm{N}$ and $\mathrm{P}$ from river water treated by the biorack wetland planted with Thaliadealbata and Acoruscalamus Linn. J. Jilin Univ. Earth Sci. Ed. 71: 408-414.

Wang, J., Zhang, L., Lu, S., Jin, X. and Gan, S. (2012a). Contaminant removal from low concentration polluted river water by the bio-rack wetlands. Environ. Sci.24 : 1006-1013.

Wang, Q. and Cheng, S.P. (2010). Review on Phytoremediation of Heavy Metal Polluted Water by Macrophytes. Environmental Science and Technology. 33(5) : $145-156$.

Wang, X.J., Li, F.Y., Okazaki, M. and Sugisaki, M. (2003).Phyto-remediation of contaminated soil.Annual Report CESS.3 : 114-123.

Wu, L.M., Cong, H.B. and Wang, X.F. (2010). Effect of Three Kinds of Floating-bed Plants and Artificial Plants on Nitrogen and Phosphorus Removal in Water.Environmental Technology. 23(3) : 12-16.

Xiong, C.H., Xu, X.G. and Lu, Y.E. (2012). Canna Indica and Acoruscalamus Ecological Floating Beds for Purification of Micro-Polluted Source Water.ActaHorticulturaeSinica. 39(12) : 2385-2394.

Xu, G.F. (2010). Study on Purified Efficiency of Phosphorus and Nitrogen from Eutrophicated Landscape Water by Four Floating Ornamental Plants. Chinese Agricultural Science Bulletin. 26(7) : 299-302.

$\mathrm{Xu}, \mathrm{H} . \mathrm{W}$. and Lu, Y. (2011).Research Advances of Aquatic Plants in Water Ecological Restoration.Chinese Agricultural Science Bulletin. 27(3) : 413-416.

Yan, C.Z., Zeng, A.Y. andJin, X.C. (2006). Equilibrium Sorption Isotherm for $\mathrm{Cu}_{2}^{+}$onto HydrillaverticillataRoyle and Myriophyllumspicatum. Environmental Science. 27(6) : 1068-1072.

Yang, C.S., Lan, C.Y. and Shu, W.S. (2002). Accumulation and Distribution of Heavy Metals in Artificial Wetland with Typhalatifolia.Water Treatment Technology. 28 (2) : 101-104.

Yu, J., Huang, C.X. and Liang, Q. (2012).Disposal of Coppercontaminated Water with Canna indica Ecological Floating Bed.Anhui Agricultural Sciences. 40(12) : 7331-7333.

Zhang, Y.M., Gao, Y.X. and Wu, X.M. (2010). Effect of the Technique of Complex Three-Dimensional Ecological Floating-Bed in Removing N and P From Slightly Polluted Water Body. Journal of Ecology and Rural Environment. 26(51) : 24-19.

Zhao, F.L., Xi,S. and Yang, X.E. (2011). Purifying Eutrophic River Waters with Integrated Floating Island Systems.Ecological Engineering.40 : 53-60.

Zhen, J.F., Luo, G.Y. and Xu, X.Y. (2008). Purification of Heavily Polluted River Water by Ecological Floating Bed at Low Temperatures.China Water \& Wastewater, 24(21) : 17-20.

Zhen, Y.Z., Li, G. and Du, J. (2013).Effect of Biological Floating Island on Water Quality and Algae in a Tributary Bay Typical of the Three-Gorge Reservoir.Journal of Ecology and Rural Environment. 29(3) : 278-283.

Zhou, C.F., An, S.Q. and Jiang, J.H. (2006). An in Vitro Propagation Protocol of Two Submerged Macrophytes for Lake Revegetation in East China.Aquatic Bota$n y .85: 44-52$. 